\title{
Article \\ Physiological Responses of Salinized Fenugreek (Trigonella foenum-graecum L.) Plants to Foliar Application of Salicylic Acid
}

\author{
Reda E. Abdelhameed ${ }^{1, *}$, Arafat Abdel Hamed Abdel Latef ${ }^{2, *(D)}$ and Rania S. Shehata ${ }^{1,3}$ \\ 1 Botany and Microbiology Department, Faculty of Science, Zagazig University, Zagazig 44519, Egypt; \\ rshahta@jazanu.edu.sa \\ 2 Department of Biology, Turabah University College, Turabah Branch, Taif University, P.O. Box 11099, \\ Taif 21944, Saudi Arabia \\ 3 Biology Department, Faculty of Science, Jazan University, Jizan 45142, Saudi Arabia \\ * Correspondence: remahdi@zu.edu.eg (R.E.A.); a.moawd@tu.edu.sa or moawad76@gmail.com (A.A.H.A.L.)
}

Citation: Abdelhameed, R.E.;

Abdel Latef, A.A.H.; Shehata, R.S.

Physiological Responses of Salinized

Fenugreek (Trigonella foenum-graecum

L.) Plants to Foliar Application of

Salicylic Acid. Plants 2021, 10, 657.

https://doi.org/10.3390/

plants10040657

Academic Editor: Ágnes Szepesi

Received: 24 February 2021

Accepted: 29 March 2021

Published: 30 March 2021

Publisher's Note: MDPI stays neutral with regard to jurisdictional claims in published maps and institutional affiliations.

Copyright: (c) 2021 by the authors. Licensee MDPI, Basel, Switzerland. This article is an open access article distributed under the terms and conditions of the Creative Commons Attribution (CC BY) license (https:// creativecommons.org/licenses/by/ $4.0 /)$.

\begin{abstract}
Considering the detrimental effects of salt stress on the physiological mechanisms of plants in terms of growth, development and productivity, intensive efforts are underway to improve plant tolerance to salinity. Hence, an experiment was conducted to assess the impact of the foliar application of salicylic acid (SA; $0.5 \mathrm{mM}$ ) on the physiological traits of fenugreek (Trigonella foenumgraecum L.) plants grown under three salt concentrations $(0,75$, and $150 \mathrm{mM} \mathrm{NaCl})$. An increase in salt concentration generated a decrease in the chlorophyll content index (CCI); however, the foliar application of SA boosted the CCI. The malondialdehyde content increased in salt-stressed fenugreek plants, while a reduction in content was observed with SA. Likewise, SA application induced an accumulation of proline, total phenolics, and flavonoids. Moreover, further increases in total free amino acids and shikimic acid were observed with the foliar application of SA, in either control or salt-treated plants. Similar results were obtained for ascorbate peroxidase, peroxidase, polyphenol oxidase, and catalase with SA application. Hence, we concluded that the foliar application of SA ameliorates salinity, and it is a growth regulator that improves the tolerance of fenugreek plants under salt stress.
\end{abstract}

Keywords: antioxidant enzymes; phenolics; fenugreek; flavonoids; proline; salicylic acid; salt stress; shikimic acid

\section{Introduction}

Abiotic stresses have been documented as the chief threat to agricultural efficiency all over the world. Anthropogenic activities in the developmental era have intensified the degradation of the agricultural system and its productivity due to the foremost abiotic stresses, such as extreme temperatures, salinity, drought, nutrients (deficiency and excess), metals/metalloids, and UV radiation [1-4], which can potentially influence almost all plant metabolic processes and which may negatively affect $70 \%$ of crops' yields [5]. One of these abiotic stresses is salinity, which threatens the agricultural system and affects all physiological processes, from seed germination to plant development, leading to reduced growth and yield [6-8]. The detrimental effects of salinity on plant physiology are associated with specific low water potential in soil solution (drought stress), ion effects, nutritional disparities, forwarding of energy from growth to pull out pure water from the saline water and to create defensive chemicals, or a combination of these altered factors $[9,10]$.

Sensitivity to salt stress is mainly due to oxidative stress, which arises from a disturbance of the balance between the production and elimination of reactive oxygen species (ROS) such as superoxide, hydrogen peroxide, and hydroxyl radicals [11]. Furthermore, lipids, specifically polyunsaturated fatty acids, are sensitive to deterioration by ROS, inducing changes in the structural and functional properties of the cells [12,13]. Previous 
studies have confirmed the accumulation of lipid peroxidation products in salt-stressed plants, and the leakiness of membranes [14,15].

Recently, great efforts have been exerted to increase the protective mechanisms of plants against salt stress. One of these promising efforts is the application of phytohormones, such as salicylic acid (SA), which is a phenolic phytohormone that acts as a signaling molecule [16]. SA plays an essential function in the regulation of seed germination and plant growth and development [17]. Ion uptake and transport, stomatal conductance, the photosynthetic rate, and transpiration [18,19] could also be affected by SA application. Exogenous SA application to stressed plants, either through seed soaking, adding to the nutrient solution, irrigation, or spraying, has been reported to augment stress tolerancemechanisms [20,21] against metals [22], salinity [13], drought [23], and heat stress [24]. A direct physiological impact of SA is the modification of antioxidant enzyme actions to increase plant responses to these stresses [25]. Moreover, SA increases plant growth under salt stress, which could be attributed to considerable enhancement in the net photosynthetic rate [26]. El-khodary [27] observed a considerable enhancement in growth characteristics, pigment contents, photosynthetic rate, and carbohydrate content in maize sprayed with SA. Additionally, SA has been shown to ameliorate salt stress in seedlings of cucumbers [28] and cowpea plants [14].

With the purpose of improving whole-plant performance under amplified severity of salt stress, more information is required about the contribution of SA to salt stress tolerance in plants at the physiological level. Among the various plants tested, fenugreek (Trigonella foenum gracium L.) is an annual leguminous herb regarded as a multi-purpose crop, that is extensively cultivated in most regions of the world for its medicinal value [29]. The use of different parts of the fenugreek plant as flavoring agents, stabilizers, adhesives, or for cosmetics, papers, and paints has also been documented [30]. It is considered a salt-sensitive plant species which is harmfully affected by salt stress in terms of physiology and growth [31,32]. Therefore, this experiment aimed to determine whether exogenous SA application could convey salt tolerance to fenugreek plants at the physiological level, based on various biochemical parameters, osmolytes, and antioxidative enzymes.

\section{Results}

\subsection{Chlorophyll Content Index}

The results in Table 1 reveal that CCI decreased with increasing salt concentration; however, the foliar application of SA had prominent effects, and an increase in the CCI of fenugreek leaves was observed.

Table 1. Effect of $\mathrm{NaCl}$ concentrations and salicylic (SA) application on the chlorophyll content index (CCI) and carbohydrate content of fenugreek plant leaves.

\begin{tabular}{|c|c|c|c|c|c|}
\hline $\mathrm{NaCl}(\mathrm{mM})$ & $\mathrm{SA}(\mathrm{mM})$ & CCI & $\% \mathrm{C}$ & Carbohydrates (mg g $\left.{ }^{-1} \mathrm{DW}\right)$ & $\% \mathrm{C}$ \\
\hline \multirow{2}{*}{0} & 0 & $22.03 \pm 0.91 \mathrm{ab}$ & \multirow{2}{*}{11.3} & $79.2 \pm 4.5 \mathrm{c}$ & \multirow{2}{*}{4.3} \\
\hline & 0.5 & $24.51 \pm 3.08 \mathrm{a}$ & & $82.6 \pm 4.6 \mathrm{bc}$ & \\
\hline \multirow{2}{*}{75} & 0 & $17.87 \pm 1.11 \mathrm{~b}$ & \multirow{2}{*}{$35.3 \uparrow$} & $91 \pm 5.1 \mathrm{bc}$ & \multirow{2}{*}{$8.4 \uparrow$} \\
\hline & 0.5 & $24.17 \pm 4.61 \mathrm{a}$ & & $98.6 \pm 5.5 \mathrm{ab}$ & \\
\hline \multirow{2}{*}{150} & 0 & $13.27 \pm 3.56 \mathrm{c}$ & \multirow{2}{*}{$32.1 \uparrow$} & $110.4 \pm 6.1 \mathrm{a}$ & \multirow{2}{*}{$7.8 \uparrow$} \\
\hline & 0.5 & $17.53 \pm 3.65 b$ & & $119 \pm 7.3 \mathrm{a}$ & \\
\hline
\end{tabular}

Data shown in the table represent the mean \pm standard error, followed by a small letter; similar letters indicate that means were not different significantly at $5 \%$, probability based on Tukey's test. \%C means SA-treated plants expressed as \% of their respective non-treated controls. DW—-dry weight, $\uparrow$ means increase. 


\subsection{Total Soluble Carbohydrates}

Table 1 shows carbohydrates accumulation in NaCl-treated fenugreek plants, compared to the control. Further accumulation of carbohydrates was detected in NaCl-treated and non-treated plants with foliar application of SA, but in salinized plants (75 and $150 \mathrm{mM}$ $\mathrm{NaCl}$ ) this accumulation was significantly higher relative to the control. Indeed, with SA application, a significant increase by $8.4 \%$ and $7.8 \%$ in carbohydrate content was observed in plants grown under 75 and $150 \mathrm{mM} \mathrm{NaCl}$, respectively, as compared with salinized plants only.

\subsection{Total Free Amino Acid Content}

Figure $1 \mathrm{~A}$ reveals a significant $(p \leq 0.05)$ increase in the total free amino acid content due to $\mathrm{NaCl}$ treatment and SA application, compared to control. Although salt stress increased the free amino acid content in fenugreek leaves, this increase was more conspicuous with SA application, realizing a maximum $\left(7.920 \mathrm{mg} \mathrm{g}^{-1} \mathrm{DW}\right)$ increase at $150 \mathrm{mM}$ $\mathrm{NaCl}$ treatment over salinized plants only $\left(5.999 \mathrm{mg} \mathrm{g}^{-1} \mathrm{DW}\right)$.

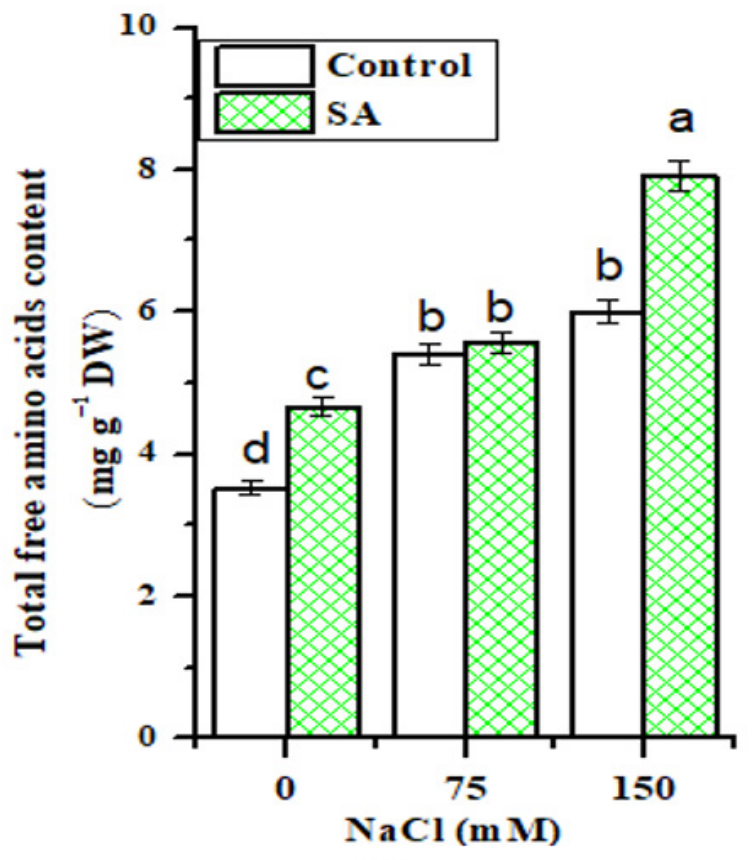

(A)

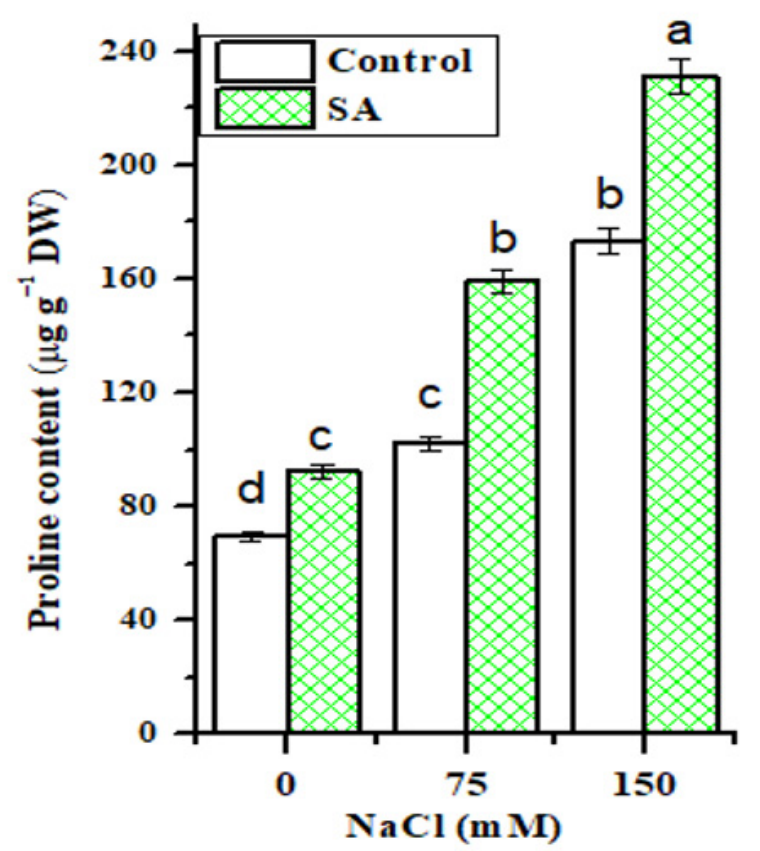

(B)

Figure 1. Effect of $\mathrm{NaCl}$ concentrations and salicylic (SA) application on (A) total free amino acid content and (B) proline content of fenugreek plant leaves. Values represent the mean of three replicates. Different letters (a,b, c and d) indicate statistical differences at 5\% probability according to Tukey's test. Error bars are standard errors of the mean. DW—dry weight.

\subsection{Proline Content}

The results in Figure 1B indicate that the proline content increased in response to $\mathrm{NaCl}$ stress, and the proline level was augmented with increasing salt concentration compared to control. Furthermore, with SA application, a significant increase $(p \leq 0.05)$ in proline content in salt-stressed fenugreek plants at the levels of 75 and $150 \mathrm{mM} \mathrm{NaCl}$ concentration was detected, when compared with their respective salinized plants only.

\subsection{Total Phenolics and Flavonoids}

The data of the total phenolic and flavonoid contents in the fenugreek leaves are shown in Figure 2. With increasing salt concentration, there was a considerable increase in total phenolic and flavonoid contents in the fenugreek leaves. Further increases in their contents were observed with SA application, in either control or salt-treated plants. For 
instance, at $150 \mathrm{mM} \mathrm{NaCl}$, the total phenolic content was about 2-fold ( $\left.4.716 \mathrm{mg} \mathrm{g}^{-1} \mathrm{DW}\right)$ higher than that of the control $\left(2.473 \mathrm{mg} \mathrm{g}^{-1} \mathrm{DW}\right)$ due to SA spraying (Figure 2A). In plants challenged by 75 and $150 \mathrm{mM} \mathrm{NaCl}$, the increases in the flavonoid content were $59.3 \%$ and $101 \%$; these percentages were boosted by $65.3 \%$ and $122 \%$, respectively, with SA application versus control in untreated plants only (Figure 2B).

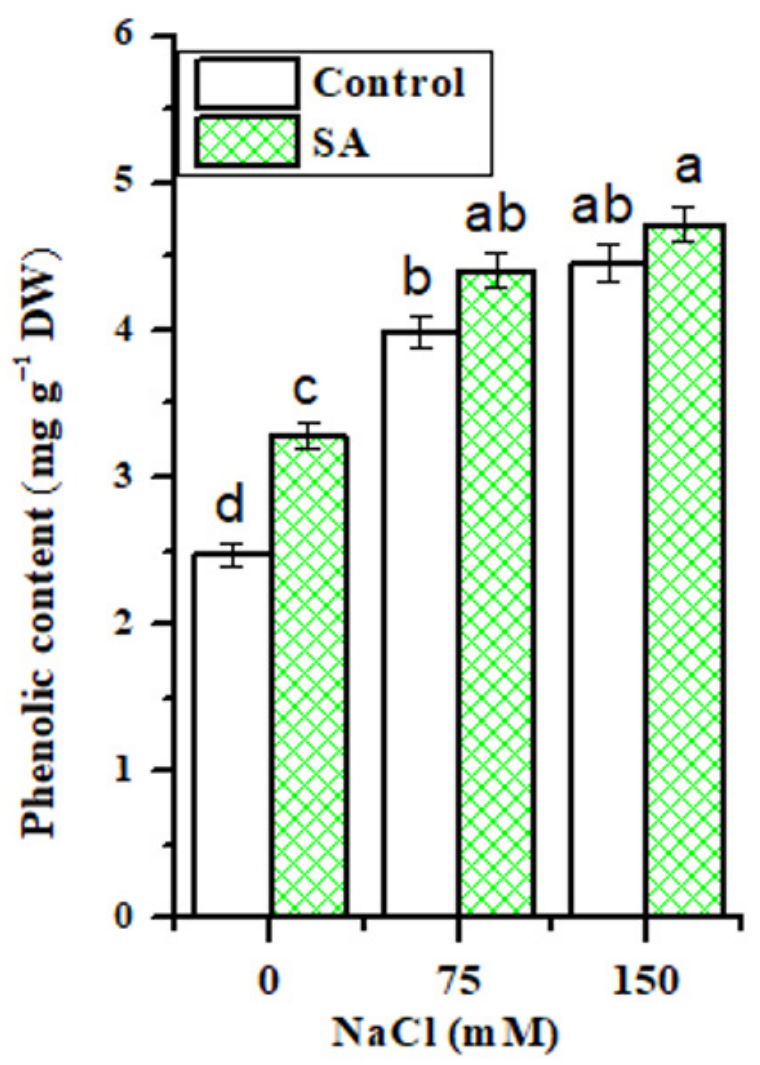

(A)

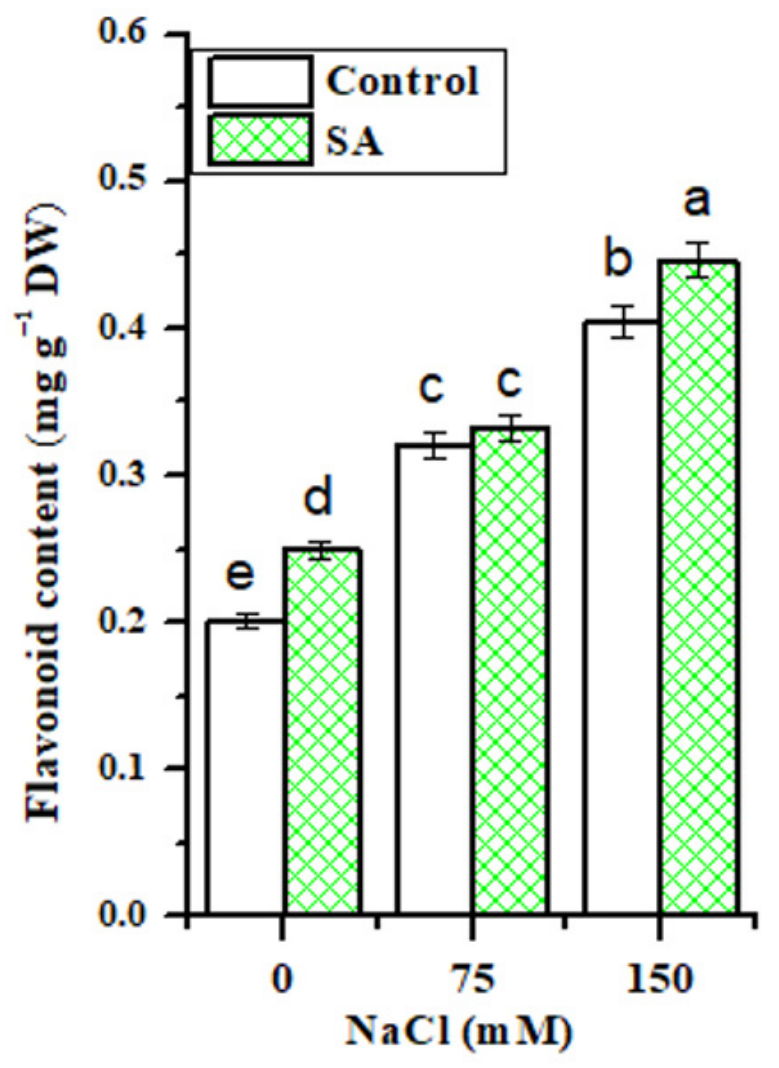

(B)

Figure 2. Effect of $\mathrm{NaCl}$ concentrations and salicylic (SA) application on (A) phenolic content and (B) flavonoid content of fenugreek plant leaves. Values represent the mean of three replicates. Different letters ( $a, b, c, d$ and e) indicate statistical differences at $5 \%$ probability according to Tukey's test. Error bars are standard errors of the mean. DW-dry weight.

\subsection{Lipid Peroxidation}

Results of the present study revealed significant changes in MDA content in saltstressed fenugreek leaves, influenced by SA application (Figure 3A). It was noted that with SA application, MDA content was significantly lower than in non-SA applied plants. On the other hand, there was a significant $(p \leq 0.05)$ increase in MDA content with increasing salt concentrations. In non-SA applied plants, an increase by $93.6 \%$ and $173.9 \%$ in MDA content was observed at 75 and $150 \mathrm{mM} \mathrm{NaCl}$, respectively. Conversely, a lower MDA content was detected with SA spraying (by $32.2 \%$ and $23.1 \%$ ) at 75 and $150 \mathrm{mM}$, respectively, versus salinized plants only.

\subsection{Shikimic Acid Content}

Among the tested parameters observed under stress conditions, the highest fluctuations in values of shikimic acid content were observed as a response to salt treatment. The increase in shikimic acid content ranged from 0.553 to $0.589 \mathrm{mg} \mathrm{g}^{-1} \mathrm{DW}$ at 75 and $150 \mathrm{mM} \mathrm{NaCl}$, compared to control $\left(0.487 \mathrm{mg} \mathrm{g}^{-1} \mathrm{DW}\right.$, Figure 3B). Of particular note, a further increase in its content was observed with foliar application of $0.5 \mathrm{mM} \mathrm{SA}$, either in control or salt-treated plants. However, in salt-treated plants, this enhancement was 
significantly greater relative to the control realizing 0.586 to $0.713 \mathrm{mg} \mathrm{g}^{-1} \mathrm{DW}$ at 75 and $150 \mathrm{mM} \mathrm{NaCl}$. Further, in terms of two-way ANOVA results (Table 2) for shikimic acid content in the leaves of fenugreek plants, significant changes were observed between salt, SA treatment, and their interactions.

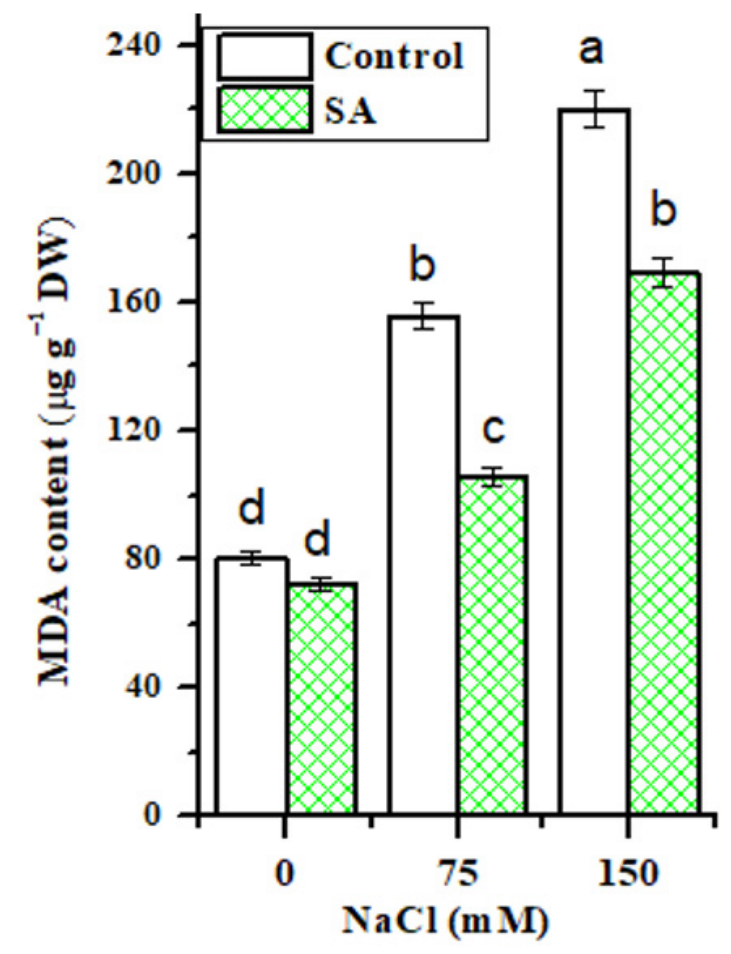

(A)

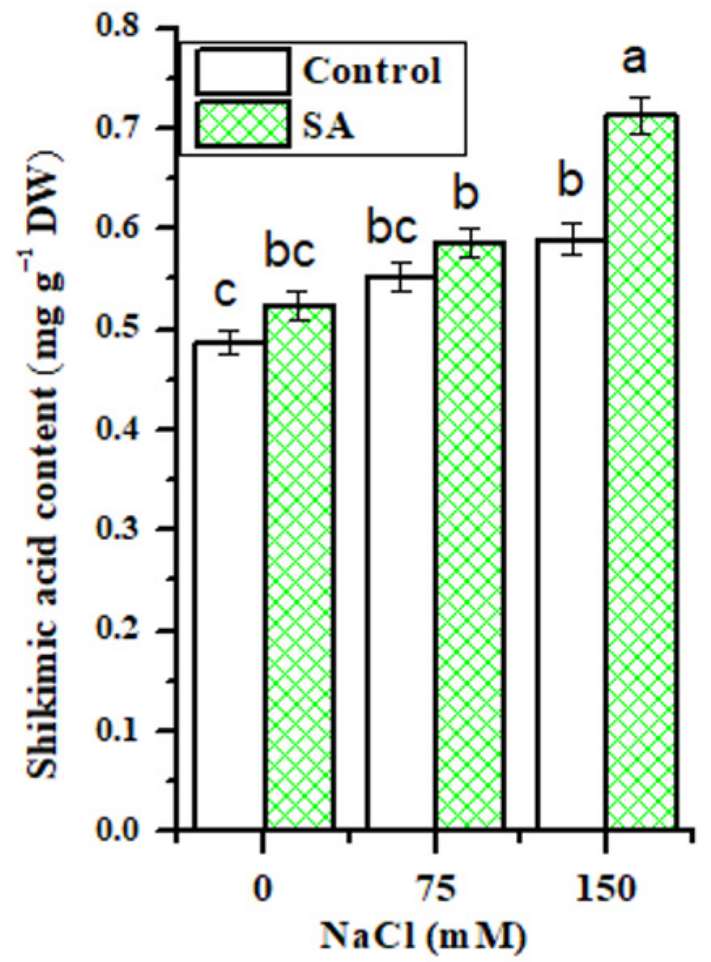

(B)

Figure 3. Effect of $\mathrm{NaCl}$ concentrations and salicylic (SA) application on (A) malondialdehyde (MDA) content and (B) shikimic acid content of fenugreek plant leaves. Values represent the mean of three replicates. Different letters $(a, b$ and $c)$ indicate statistical differences at 5\% probability according to Tukey's test. Error bars are standard errors of the mean. DW; dry weight.

Table 2. Analysis of variance of the effect of salt, salicylic (SA), and their interactions on some physiological parameters in fenugreek leaves, based on a two-way ANOVA analysis.

\begin{tabular}{cccc}
\hline Parameters & Salt & SA & Salt $\times$ SA \\
\hline Chlorophyll content index & $*$ & $*$ & ns \\
\hline Carbohydrates & $*$ & $*$ & ns \\
\hline Lipid peroxidation & $*$ & $*$ & ns \\
\hline Phenolics & $*$ & $*$ & $\mathrm{~ns}$ \\
\hline Flavonoids & $*$ & $*$ & $*$ \\
\hline Shikimic acid & $*$ & $*$ & $*$ \\
\hline Total free amino acids & $*$ & $*$ & $\mathrm{~ns}$ \\
\hline Proline & $*$ & $*$ & $\mathrm{~ns}$ \\
\hline POD & $*$ & $*$ & $*$ \\
\hline CAT & $*$ & $*$ & $*$ \\
\hline APX & $*$ & $*$ & $*$ \\
\hline PPO & $*$ & & \\
\hline
\end{tabular}

ns (non-significant) and ${ }^{*}$ (significant at the $5 \%$ probability level). 


\subsection{Antioxidative Enzymes}

Salt stress significantly induced an increase in the enzymatic antioxidant profiles of fenugreek leaves, including POD, CAT, PPO, and APX activities (Figure 4). Moreover, the application of SA significantly $(p \leq 0.05)$ improved their activities (Figure $4 A-D)$, either in control or NaCl-stressed fenugreek plant leaves. Under normal conditions, SA application significantly increased APX and POD activities (by $27.6 \%$ and $53.5 \%$, respectively) in comparison with control. At $150 \mathrm{mM} \mathrm{NaCl}$, SA application significantly augmented the activities of POD, APX, and PPO in fenugreek leaves by $42.1 \%, 8.1 \%$ and $14.1 \%$, respectively, as compared to $\mathrm{NaCl}$-treated plants alone. Most interestingly, based on two-way ANOVA results (Table 2), significant differences were established among salt, SA treatment, and their interactions in the antioxidant enzymes of fenugreek plant leaves.

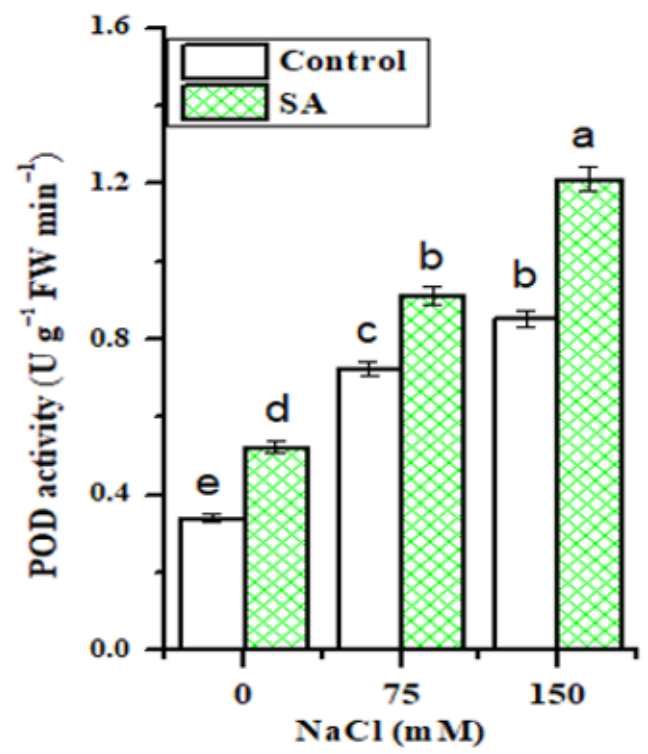

(A)

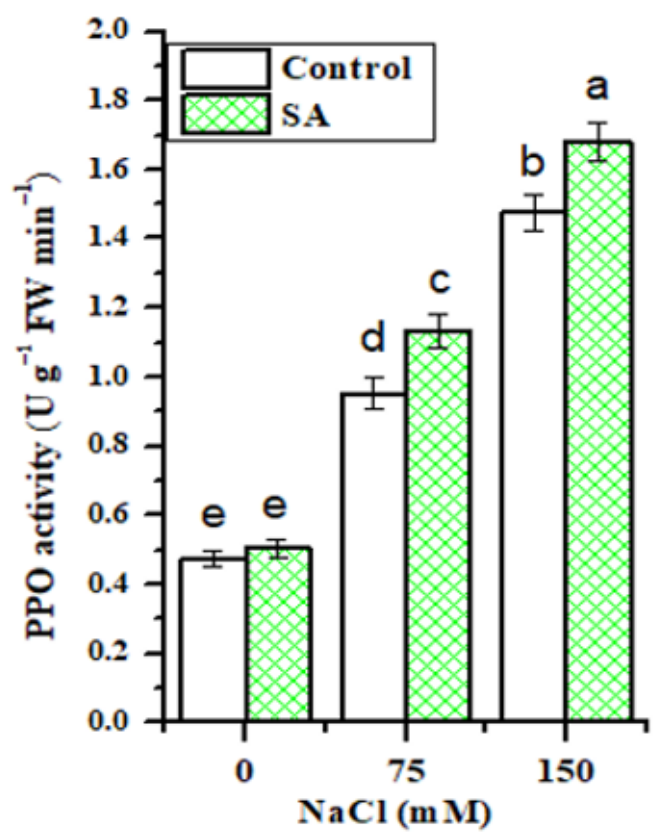

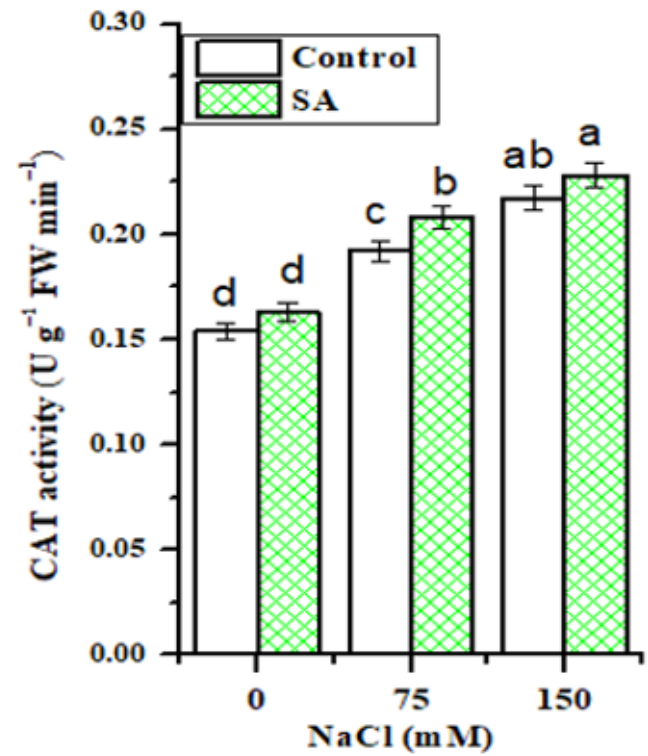

(B)

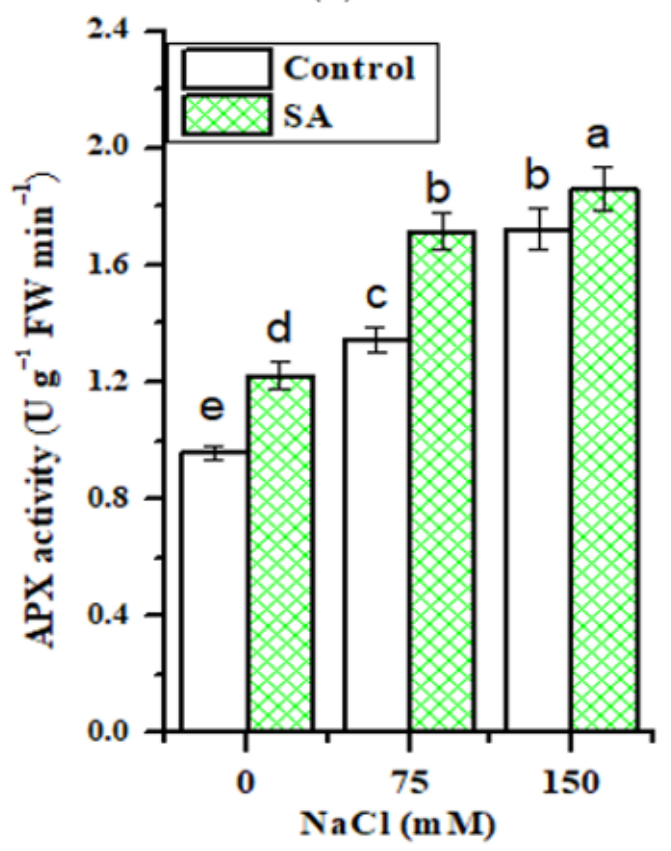

Figure 4. Effect of $\mathrm{NaCl}$ concentrations and salicylic (SA) application on antioxidant enzymes activities; (A) peroxidase (POD), (B) catalase (CAT), (C) polyphenol oxidase (PPO) and (D) ascorbate peroxidase (APX), of fenugreek plants. Values represent the mean of three replicates. Different letters $(a, b, c, d$ and e) indicate statistical differences at $5 \%$ probability according to Tukey's test. Error bars are standard errors of the mean. DW; dry weight. 


\section{Discussion}

Chlorophyll content is widely used as an indicator of abiotic tolerance in plants, as changes in chlorophyll content are linked to visual symptoms of plant illness and photosynthetic efficiency [33]. A decline in chlorophyll content in salt-applied fenugreek plants might be ascribed to the possible oxidation of chlorophyll and other chloroplast pigments, coupled with the instability of the pigment-protein complex under salt stress [34]. Similar results were obtained in cowpea plants by [14] and [35] under salt stress conditions. Reduction in the chlorophyll content can be reversed back to a similar level as the control by the foliar application of SA, which might account for the induction of Rubisco activity and synthesis of more carbohydrates in treated plants [24]. SA application may also inhibit the production and accumulation of ROS in plant tissues, which negatively affects the photosynthetic unit.

The increase in carbohydrate content in fenugreek plants grown in soil treated with 75 and $150 \mathrm{mM} \mathrm{NaCl}$ could be related to the major role of these carbohydrates in stress alleviation, involving osmoprotectants, carbon storage, and signal molecules. It was reported that carbohydrates such as sugars (e.g., glucose, fructose, fructans, and trehalose) and starch are involved in the response to several stresses, and act as nutrient and metabolite signaling molecules [36,37]. Additionally, the high carbohydrate accumulation helps to prevent oxidative losses by scavenging ROS and maintaining protein structure during salt stress. Moreover, the marked increase in carbohydrate levels in fenugreek leaves following SA application corroborated the findings of $[27,38,39]$. SA application deranges the enzymatic system of polysaccharide hydrolysis, which stimulates the hydrolysis of insoluble sugars and creates an osmotic source that is important to osmotic regulation. Interestingly, it can be concluded that SA application ameliorates salinity stress by increasing photosynthetic carbohydrates.

Amino acids are essential molecules that shuttle organic nitrogen through the plant, and play several critical roles in plants, from providing the building blocks of proteins to their central role in cellular and plant physiology [40,41]. The increase in amino acid content in fenugreek plants as a result of salt stress and SA application may be attributed to the changes produced by stress promoting the synthesis of amino acids, inhibiting amino acid degradation, and inhibiting protein synthesis and protein degradation [42]. Moreover, amino acids are involved in glutathione and phytochelatin synthesis, which play roles in metal binding and synthesis of polyamines, acting as signaling molecules and antioxidants [43]. Therefore, it could be hypothesized that amino acids contribute to maintaining the cellular osmotic potential, and may have an important role in tolerance to salt stress.

Generally, proline accumulation is an important physiological index for plant response to salt stress and is supposed to correlate with adaptation to salinity [44]. The obtained result of increasing proline content in fenugreek leaves supports earlier reports by [45], in which salinity displayed a conspicuous increase in compatible solutes, such as proline. Hence, the accumulated proline level under salt stress may be due to the activation of proline biosynthesis, which enhances protein turnover [30]. A noteworthy finding from our study is that the use of the plant-growth-hormone (SA) significantly increased the proline content in fenugreek plants under both saline and non-saline conditions, as previously reported by [46] in chickpea plants. Plants require a greater accumulation of energy-rich compounds under a saline soil environment. From these compounds, proline serves as a nitrogen and/or carbon source, or as a building block for peptide and protein synthesis [47]. Moreover, proline acts as a scavenger of free radicals [48], and a cytoplasmic osmolyte that reduces the osmotic potential of the cell and the uptake of toxic ions [49].

Similarly, phenolic compounds, a group of secondary metabolites, have different biological activities, and their most important capability is their antioxidant activity in plants $[50,51]$. Our study indicated the role of SA application in minimizing the harmful effects of salt stress, with evidence of an increase in the protective effects of these compounds 
against salt stress, supporting plants to maintain ROS levels under detrimental conditions, and facilitating rapid elimination so that metabolism remains stable.

Moreover, the results of a flavonoid increase in fenugreek leaves agreed with earlier studies of [52] on artichoke (Cynara scolymus L.) leaves, which may be explained by the finding that enzymes of the flavonoid biosynthesis pathway, such as phenylalanine ammonia-lyase and chalcone synthase, increase under stress [53]. Additionally, flavonoids directly scavenge $\mathrm{ROS}$, including $\mathrm{H}_{2} \mathrm{O}_{2}, \mathrm{O}_{2}{ }^{-}$and $\mathrm{OH}^{-}$radicals. Furthermore, flavonoids were found to enrich plant tolerance against salinity by regulating $\mathrm{K}^{+}$maintenance and $\mathrm{Na}^{+}$elimination from leaf mesophyll in broad beans and quinoa [54].

Lipid peroxidation is the process whereby free radicals steal electrons from the lipids in cell membranes, leading to a free radical chain reaction mechanism that indicates the magnitude of the oxidative stress, resulting in cell damage and the formation of MDA [55-57]. The accumulation of MDA in fenugreek leaves subjected to salt stress was ascribed to the production of ROS in cells, which causes peroxidation in membranous lipids and the formation of MDA. The reduction in its content in fenugreek plants following SA application could be attributed to the fact that SA supports plants to produce antioxidative compounds and/or enzymes that diminish ROS before peroxidation [14].

Interestingly, the increase in shikimic acid in fenugreek leaves subjected to salt stress and sprayed with SA was in agreement with the previously observed results of [58-60] for maize, Eucalyptus and carrot, respectively, under different stress conditions. It was proven that the accumulation of shikimic acid depends on the rate of ongoing metabolic processes [61], which leads to the synthesis of plant phenolic compounds via the shikimic acid pathway. This pathway simply converts simple carbohydrate precursors derived from glycolysis and the pentose phosphate pathway into aromatic amino acids, including the SA precursor phenylalanine [62], which could be correlated with the pivotal effect that SA exerts during the plant response to salinity.

The increase in antioxidant enzyme activity in fenugreek plant leaves under salt stress confirms earlier reports [38]. Salinity led to a prominent increase in antioxidant enzymes, which may be due to the reality that ROS are produced in response to different environmental stresses, including salt stress $[63,64]$.

Of particular note, a significant $(p \leq 0.05)$ increase in antioxidant enzyme activity following SA application could be the sign of buildup of a protective means to lessen the oxidative damage induced by salt stress. A similar observation was recorded by [65] on soybean plants under the combination of salt stress and SA application, and by [66] under $\mathrm{Cd}$ stress. The augmentation of oxidative stress caused by salinity may be overwhelmed by this enzymatic system, and this explains our previously mentioned result of a decrease in MDA content in SA applied fenugreek plants.

\section{Materials and Methods}

\subsection{Soil, Seed, and Growth Conditions}

The experimental soil was collected from the top layer $(0-20 \mathrm{~cm})$ from Sharkia Governate, Egypt. Physicochemical attributes and nutritional status of the experimental soil are recorded in Table 3. Fenugreek seeds (Trigonella foenum-graecum L.) (var. Giza 30; procured from Agricultural Research Centre, Giza, Egypt) were surface disinfected with 5\% sodium hypochlorite for $10 \mathrm{~min}$, then subsequently washed with distilled water and sown in plastic pots $(25 \mathrm{~cm}$ diam.) filled with $2 \mathrm{~kg}$ of the collected soil. The experiments were kept under controlled conditions ( $10 \mathrm{~h}$ light $/ 14 \mathrm{~h}$ dark cycle at $20 / 15^{\circ} \mathrm{C}$ (day/night), moistened repeatedly with water, and thinned to five germinated seeds per pot after 10 days of germination. 
Table 3. Physicochemical properties and nutritional status of the experimental soil before planting.

\begin{tabular}{|c|c|c|c|c|c|c|c|c|c|c|c|c|c|}
\hline \multirow{3}{*}{ Property } & \multirow{3}{*}{$\begin{array}{c}\text { Sand } \\
(\%)\end{array}$} & \multirow{3}{*}{$\begin{array}{l}\text { Silt } \\
(\%)\end{array}$} & \multirow{3}{*}{$\begin{array}{l}\text { Clay } \\
(\%)\end{array}$} & \multirow{3}{*}{$\begin{array}{c}\text { Soil } \\
\text { Texture }\end{array}$} & \multirow{3}{*}{$\begin{array}{l}\text { Saturation } \\
\text { Percent }\end{array}$} & \multirow{3}{*}{$\begin{array}{c}\text { Electric } \\
\text { Conductivity }\end{array}$} & \multirow{3}{*}{$\mathrm{pH}$} & \multirow{3}{*}{$\begin{array}{c}\mathrm{CaCO}_{3} \\
(\%)\end{array}$} & \multicolumn{4}{|c|}{ Mineral Content } & \multirow{3}{*}{$\begin{array}{c}\begin{array}{c}\text { Organic } \\
\text { Matter }\end{array} \\
(\%)\end{array}$} \\
\hline & & & & & & & & & \multicolumn{3}{|c|}{ (mg/kg Soil) } & \multirow{2}{*}{$\begin{array}{c}(\%) \\
\text { Total P } \\
\end{array}$} & \\
\hline & & & & & & & & & $\mathrm{K}$ & Mg & $\mathrm{Ca}$ & & \\
\hline Value & 13.9 & 27.4 & 58.7 & clay & 69 & 3.4 & 8.2 & 4.9 & 0.37 & 6.3 & 8.4 & 0.69 & 1.2 \\
\hline
\end{tabular}

\subsection{Salt and Salicylic Acid Application}

Salt solutions were applied after one month from sowing at the levels of 0,75 and $150 \mathrm{mM} \mathrm{NaCl}$, then SA was applied after finishing the salt addition by spraying the fenugreek plant leaves with $0.5 \mathrm{mM}$ SA solution, versus no SA (control sprayed with distilled water) in the early morning for seven successive days. Hence, there were six treatments $(2 \times 3)$, and each treatment was replicated three times $(2 \times 3 \times 3)$. The plant samples from all treatments were collected after 4 weeks from SA application and kept in labeled bags for different analysis.

\subsection{Physiological Evaluation}

\subsubsection{Estimation of Chlorophyll}

The chlorophyll content index (CCI) in fenugreek leaves was estimated by the CCM200 plus Chlorophyll Content Meter (Opti-Sciences, Inc., Hudson, NH, USA). CCI results are the mean of the data recorded at different positions along the length of the leaf.

\subsubsection{Estimation of Carbohydrate Content}

Carbohydrates were estimated by the phenol sulphuric acid technique, as confirmed by [67]. A known weight of dried fenugreek leaves was extracted with $2.5 \mathrm{~N} \mathrm{HCl}$. The absorbance was read at $490 \mathrm{~nm}$.

\subsubsection{Determination of Total Free Amino Acids and Proline Content}

The total free amino acid content of fenugreek leaf tissue was assessed quantitatively in an alcoholic extract by the method of [68]. Ninhydrin solution, citrate buffer, glycerol $(55 \%)$, and $0.5 \mathrm{~mL}$ of sample solution were mixed subsequently, and the volume was brought up to $5 \mathrm{~mL}$ by distilled water. After heating in a boiling water bath for half an hour, the mixture was then cooled under tap water and gently shaken. The absorbance was read at $570 \mathrm{~nm}$.

The proline content of fresh leaves was extracted in 3\% aqueous sulphosalicylic acid, and the homogenate was filtered. Two $\mathrm{mL}$ of glacial acetic acid and $2 \mathrm{~mL}$ of acid ninhydrin were added to $2 \mathrm{~mL}$ of the filtrate in a glass test tube and heated in a boiling water bath for $1 \mathrm{~h}$, and then were placed in an ice bath. Four $\mathrm{mL}$ of toluene was added to the reaction mixture and stirred well for 20-30 s. The optical density of the produced color was measured at $520 \mathrm{~nm}[69]$.

\subsubsection{Determination of Total Phenolic and Flavonoid Contents}

Total phenolic content in fenugreek leaves was determined [70] after 95\% ethanol extraction; then, $1 \mathrm{~mL}$ from the extract was mixed with $1 \mathrm{~mL}$ of Folin reagent and $1 \mathrm{~mL}$ of $\mathrm{Na} 2 \mathrm{CO} 3(20 \%)$. The absorbance was computed at $650 \mathrm{~nm}$.

Total flavonoid content in fenugreek leaves was assayed according to [71], using the aluminum chloride colorimetric method. A $100 \mu \mathrm{L}$ aliquot of the alcoholic extract was added to $4 \mathrm{~mL}$ of distilled water. At zero time, $0.3 \mathrm{~mL} 5 \%$ sodium nitrite was added. After $5 \mathrm{~min}, 0.3 \mathrm{~mL}$ of $10 \%$ aluminum chloride was added. After $6 \mathrm{~min}, 2 \mathrm{~mL}$ of $1 \mathrm{M}$ sodium hydroxide was added to the mixture. Absorbance was measured at $510 \mathrm{~nm}$.

\subsubsection{Determination of Malondialdehyde (MDA) Content}

Lipid peroxidation rates in fresh fenugreek leaves were determined by measuring the MDA content according to the method of [72], using thiobarbituric acid. Absorbance 
was determined at 450,532, and $600 \mathrm{~nm}$, respectively, using a spectrophotometer, and its content was estimated based on the following formula:

$$
\operatorname{MDA}(\mu \mathrm{m} / \mathrm{L})=6.45\left(\mathrm{~A}_{532}-\mathrm{A}_{600}\right)-0.56 \mathrm{~A}_{450}
$$

\subsubsection{Shikimic Acid Content}

Fresh fenugreek leaves were homogenized in $0.25 \mathrm{M} \mathrm{HCl}$ (1 mL/100 mg biomass) [73] and centrifuged at $3000 \mathrm{rpm}$ for $30 \mathrm{~min}$. Then, $0.5 \mathrm{~mL}$ of $1 \%$ periodic acid was added to $50 \mu \mathrm{L}$ of supernatant and left for $3 \mathrm{~h}$ at room temperature. After that, $0.5 \mathrm{~mL}$ of $1 \mathrm{M}$ sodium hydroxide and $0.3 \mathrm{~mL}$ of $0.1 \mathrm{M}$ glycine were added, and the samples were centrifuged again. The absorbance of the samples was read at $380 \mathrm{~nm}$.

\subsubsection{Estimation of the Antioxidant Enzymes}

A known shoot fresh weight of fenugreek was ground in $0.05 \mathrm{M}$ phosphate buffer (pH 7.0) containing $1 \mathrm{mM}$ EDTA (Ethylene Diamine Tetra Acetic Acid), and centrifuged at 10,000 rpm for $10 \mathrm{~min}$. The supernatant was finalized to a total known volume and used as an enzyme source. An assay of catalase activity (CAT) was undertaken in line with the method of [74]. Peroxidase activity (POD) was estimated based on information from [75], wherein $5 \mathrm{~mL}$ of the assay mixture, comprising $300 \mu \mathrm{M}$ phosphate buffer $(\mathrm{pH} 6.8), 50 \mu \mathrm{M}$ catechol, $50 \mu \mathrm{M} \mathrm{H}_{2} \mathrm{O}_{2}$ and $1 \mathrm{~mL}$ of enzyme extract, was prepared. The optical density was measured at $430 \mathrm{~nm}$.

An assay of polyphenol oxidase activity (PPO) was performed according to [76], wherein $5 \mathrm{~mL}$ of assay mixture comprising $125 \mu \mathrm{M}$ of phosphate buffer ( $\mathrm{pH} 6.8), 100 \mu \mathrm{M}$ of pyrogallol, and $1 \mathrm{~mL}$ of enzyme extract were prepared. The optical density of the produced color was measured at $430 \mathrm{~nm}$. Ascorbate peroxidase (APX) activity was prepared and assayed according to [77].

\subsection{Statistical Analysis}

Origin 2017 was used for data processing and forming figures. The data were subjected to statistical studies using a two-way analysis of variance (ANOVA), using the Statistical Package for the Social Science (SPSS) version 15.0. The data are presented as the means \pm standard errors of at least three replicates per treatment $(n=3)$, and the different letters indicate the statistical differences at $p<0.05$ using the post hoc test (Tukey's test).

\section{Conclusions}

It may be concluded from our results that $\mathrm{NaCl}$ had damaging effects on the chlorophyll content and biochemical parameters of fenugreek plants. SA application alleviates the devastating effects generated by salt stress, and this was evidenced by the increase in CCI, carbohydrates, phenolics, flavonoids, and total free amino acids. Increases in shikimic acid, proline, and antioxidant enzyme activity, and a lower MDA content, were also detected with SA application. Thus, it may be concluded that exogenous SA application might act as a powerful tool in enhancing physiological parameters and protecting plants from abiotic stresses, such as salt stress.

Author Contributions: Conceptualization, R.E.A.; Methodology, R.E.A.; Validation, R.E.A., A.A.H.A.L.; Formal analysis, R.E.A.; Investigation, R.E.A.; Data curation, R.E.A.; Funding acquisition, A.A.H.A.L., R.S.S., Writing, R.E.A., Review and editing, A.A.H.A.L., Supervision, A.A.H.A.L. All authors have read and agreed to the published version of the manuscript.

Funding: This research was funded by Taif University Researchers Supporting Project number (TURSP-2020/72), Taif University, Taif, Saudi Arabia.

Institutional Review Board Statement: Not applicable.

Informed Consent Statement: Not applicable. 
Data Availability Statement: No new data were created or analyzed in this study. Data sharing is not applicable to this article.

Conflicts of Interest: The authors declare no conflict of interest.

\section{References}

1. Abdel Latef, A.A.; Zaid, A.; Abo-Baker, A.B.E.; Salem, W.; Abu Alhmad, M.F. Mitigation of copper stress in maize by inoculation with Paenibacillus polymyxa and Bacillus circulans. Plants 2020, 9, 1513. [CrossRef] [PubMed]

2. Osman, M.S.; Badawy, A.A.; Osman, A.I.; Abdel Latef, A.A. Ameliorative impact of an extract of the halophyte Arthrocnemum macrostachyum on growth and biochemical parameters of soybean under salinity stress. J. Plant Growth Regul. 2020. [CrossRef]

3. Qi, Z.Y.; Ahammed, G.J.; Jiang, C.Y.; Li, C.X.; Zhou, J. The E3 ubiquitin ligase gene SIRING1 is essential for plant tolerance to cadmium stress in Solanum lycopersicum. J. Biotechnol. 2020, 324, 239-247. [CrossRef] [PubMed]

4. Dawood, M.F.A.; Tahjib-Ul-Arif, M.; Sohag, A.A.; Abdel Latef, A.A.; Ragaey, M.M. Mechanistic insight of allantoin in protecting tomato plants against ultraviolet $C$ stress. Plants 2021, 10, 11. [CrossRef]

5. Mantri, N.; Patade, V.; Penna, S.; Ford, R.; Peng, E. Abiotic stress responses in plants: Present and future. In Abiotic Stress Responses in Plants; Ahmad, P., Prasad, M.N.V., Eds.; Springer: New York, NY, USA, 2012; pp. 1-19. [CrossRef]

6. Chinnusamy, V.; Jagendorf, A.; Zhu, J.-K. Understanding and improving salt tolerance in plants. Crop. Sci. 2005, 45, 437-448. [CrossRef]

7. Abdel Latef, A.A.; Alhmad, M.F.A.; Kordrostami, M.; Abo-Baker, A.B.A.E.; Zakir, A. Inoculation with Azospirillum lipoferum or Azotobacter chroococcum reinforces maize growth by improving physiological activities under saline conditions. J. Plant Growth Regul. 2020, 39, 1293-1306. [CrossRef]

8. Al-Elwany, O.A.A.I.; Mohamed, G.F.; Abdurrahman, H.A.; Rady, M.M.; Abdel Latef, A.A. Exogenous glutathione-mediated tolerance to deficit irrigation in salt-affected Capsicum frutescence (L.) plants is connected with higher antioxidant content and ionic homeostasis. Not. Bot. Horti Agrobot. Cluj Napoca 2020, 48, 1957-1979. [CrossRef]

9. Munns, R.; Tester, M. Mechanism of salinity tolerance. Annu. Rev. Plant Biol. 2008, 59, 651-681. [CrossRef]

10. Abdel Latef, A.A.; Srivastava, A.K.; Abdel-sadek, M.S.; Kordrostam, M.; Tran, L.S.P. Titanium dioxide nanoparticles improve growth and enhance tolerance of broad bean plants under saline conditions. Land Degrad. Dev. 2018, 29, 1065-1073. [CrossRef]

11. Dief, H.; Hashem, E.A.; Fawzan, S.; El-Sayed, A.S. Alleviation of salt stress in Triticum aestivum by biopriming with Phanerochaete chrysosporium. J. Crop. Sci. Biotechnol. 2021, 24, 103-116. [CrossRef]

12. Chandrakar, V.; Dubey, A.; Keshavkant, S. Modulation of antioxidant enzymes by salicylic acid in arsenic exposed Glycine max L. J. Soil Sci. Plant Nutr. 2016, 16, 662-676. [CrossRef]

13. Abdel Latef, A.A.; Kordrostami, M.; Zakir, A.; Zaki, H.; Saleh, O.M. Eustress with $\mathrm{H}_{2} \mathrm{O}_{2}$ facilitates plant growth by improving tolerance to salt stress in two wheat cultivars. Plants 2019, 8, 303. [CrossRef] [PubMed]

14. Abdelhameed, R.E.; Metwally, R.A. Mitigation of salt stress by dual application of arbuscular mycorrhizal fungi and salicylic acid. Agrochimica 2018, 62, 353-366. [CrossRef]

15. Ahammed, G.J.; Li, Y.; Li, X.; Han, W.-Y.; Chen, S. Epigallocatechin-3-Gallate Alleviates Salinity-Retarded Seed Germination and Oxidative Stress in Tomato. J. Plant Growth Regul. 2018, 37, 1349-1356. [CrossRef]

16. Per, T.S.; Fatma, M.; Asgher, M.; Javied, S.; Khan, N.A. Salicylic Acid and Nutrients Interplay in Abiotic Stress. In Salicylic Acid: A Multifaceted Hormone; Nazar, R., Iqbal, N., Khan, N., Eds.; Springer Nature: Singapore, 2017. [CrossRef]

17. Koo, Y.M.; Heo, A.Y.; Choi, H.W. Salicylic Acid as a Safe Plant Protector and Growth Regulator. Plant Pathol. J. 2020, 36, 1-10. [CrossRef] [PubMed]

18. Hayat, Q.; Hayat, S.; Irfan, M.; Ahmad, A. Effect of exogenous salicylic acid under changing environment: A review. Environ. Exp. Bot. 2010, 68, 14-25. [CrossRef]

19. Li, X.; Zhang, L.; Ahammed, G.J.; Li, Y.-T.; Wei, J.-P.; Yan, P.; Zhang, L.-P.; Han, X.; Han, W.-Y. Salicylic acid acts upstream of nitric oxide in elevated carbon dioxide-induced flavonoid biosynthesis in tea plant (Camellia sinensis L.). Environ. Exp. Bot. 2019, 161, 367-374. [CrossRef]

20. Palma, F.; López-Gómez, M.; Tejera, N.A.; Lluch, C. Salicylic acid improves the salinity tolerance of Medicago sativa in symbiosis with Sinorhizobium meliloti by preventing nitrogen fixation inhibition. Plant Sci. 2013, 208, 75-82. [CrossRef]

21. Babar, S.; Siddiqi, E.H.; Hussain, I.; Bhatti, K.H.; Rasheed, R. Mitigating the Effects of Salinity by Foliar Application of Salicylic Acid in Fenugreek. Physiol. J. 2014, 2014, 1-6. [CrossRef]

22. Zhang, Y.; Xu, S.; Yang, S.; Chen, Y. Salicylic acid alleviates cadmium-induced inhibition of growth and photosynthesis through upregulating antioxidant defense system in two melon cultivars (Cucumis melo L.). Protoplasma 2015, 252, 911-924. [CrossRef]

23. Fayez, K.A.; Bazaid, S.A. Improving drought and salinity tolerance in barley by application of salicylic acid and potassium nitrate. J. Saudi Soc. Agric. Sci. 2014, 13, 45-55. [CrossRef]

24. Khan, M.I.R.; Iqbal, N.; Masood, A.; Per, T.S.; Khan, N.A. Salicylic acid alleviates adverse effects of heat stress on photosynthesis through changes in proline production and ethylene formation. Plant Signal. Behav. 2013, 8, e26374. [CrossRef]

25. Alsahli, A.; Mohamed, A.-K.; Alaraidh, I.; Al-Ghamdi, A.; Al-Watban, A.; El-Zaidy, M.; Alzahrani, S.M. Salicylic acid alleviates salinity stress through the modulation of biochemical attributes and some key antioxidants in wheat seedlings. Pak. J. Bot. 2019, 51, 1551-1559. [CrossRef] 
26. Noreen, S.; Ashraf, M. Alleviation of adverse effects of salt stress on sunflower (Helianthus annuus L.) by exogenous application of salicylic acid: Growth and photosynthesis. Pak. J. Bot. 2008, 40, 1657-1663.

27. El-khodary, S.F.A. Effect of salicylic acid on the growth, photosynthesis and carbohydrate metabolism in salt stressed maize plants. Int. J. Agric. Biol. 2004, 6, 5-8.

28. Shim, I.S.; Momose, Y.; Yamamoto, A.H.; Kim, D.W.A.; Usui, K. Inhibition of catalase activity by oxidative stress and its relationship to salicylic acid accumulation in plants. Plant Growth Regul. 2003, 39, 285-292. [CrossRef]

29. Petropoulos, G.A. Fenugreek-The Genus Trigonella, 1st ed.; Taylor and Francis: London, UK; New York, NY, USA, $2002 ;$ pp. 1-127.

30. Ahmad, A.; Alghamdi, S.; Mahmood, K.; Afzal, M. Fenugreek a multipurpose crop: Potentialities and improvements. Saudi J. Biol. Sci. 2016, 23, 300-310. [CrossRef]

31. Abdel Latef, A.A.; Abu Alhmad, M.F.A.; Ahmad, S. Foliar application of fresh moringa leaf extract overcomes salt stress in fenugreek (Trigonella foenum-graecum) plants. Egypt. J. Bot. 2017, 57, 157-179. [CrossRef]

32. Metwally, R.A.; Abdelhameed, R.E. Synergistic effect of arbuscular mycorrhizal fungi in growth and physiology of salt-stressed Trigonella foenum-graecum plants. Biocatal. Agric. Biotechnol. 2018, 16, 538-544. [CrossRef]

33. Selem, E.E.; Abdelhameed, R.E.; Kamel, H.A.; Hegazy, S.H. Physiological and Biochemical Response of Gamma Irradiated Sesamum indicum L. Seed Grown in Heavy Metal Contaminated Soil. Biosci. Res. 2018, 15, 1063-1072.

34. Shi, Q.; Bao, Z.; Zhu, Z.; Ying, Q.; Qian, Q. Effects of different treatments of salicylic acid on heat tolerance, chlorophyll fluorescence and antioxidant enzyme activity in seedlings of Cucumis sativa L. Plant Growth Regul. 2006, 48, 127-135. [CrossRef]

35. Abdel-Fattah, G.M.; Rabie, G.H.; Lamis, D.S.; Metwally, R.A. The impact of arbuscular mycorrhizal fungi on growth and physiological parameters of cowpea plants grown under salt stress conditions. Int. J. Appl. Sci. Biotechnol. 2016, 4, 372-379. [CrossRef]

36. Couée, I.; Sulmon, C.; Gouesbet, G.; El Amrani, A. Involvement of soluble sugars in reactive oxygen species balance and responses to oxidative stress in plants. J. Exp. Bot. 2006, 57, 449-459. [CrossRef] [PubMed]

37. Abdel Latef, A.A.; Abu Alhmad, M.F.A.; Abdelfattah, K.E. The possible roles of priming with ZnO nanoparticles in mitigation of salinity stress in lupine (Lupinus termis) plants. J. Plant Growth Regul. 2017, 36, 60-70. [CrossRef]

38. Fahad, S.; Bano, A. Effect of salicylic acid on physiological and biochemical characterization of maize grown in saline area. Pak. J. Bot. 2012, 44, 1433-1438.

39. Jini, D.; Joseph, B. Physiological Mechanism of Salicylic Acid for Alleviation of Salt Stress in Rice. Rice Sci. 2017, 24, 97-108. [CrossRef]

40. Hernandez-Montes, G.; Diaz-Mejia, J.J.; Perez-Rueda, E.; Segovia, L. The hidden universal distribution of amino acid biosynthetic networks: A genomic perspective on their origins and evolution. Genome Biol. 2008, 9, R95. [CrossRef]

41. Abdel Latef, A.A.; Srivastava, A.K.; Saber, H.; Alwaleed, E.A.; Tran, L.S.P. Sargassum muticum and Jania rubens regulate amino acid metabolism to improve growth and alleviate salinity in chickpea. Sci. Rep. 2017, 7, 10537. [CrossRef]

42. Mansour, M.M. Nitrogen containing compounds and adaptation of plants to salinity stress. Biol. Plant. 2000, 43, 491-500. [CrossRef]

43. Sharma, S.S.; Dietz, K.J. The significance of amino acids and amino acid-derived molecules in plant responces and adaptation to heavy metal stress. J. Exp. Bot. 2006, 57, 711-726. [CrossRef]

44. Ashraf, M.; Harris, P.J.C. Potential biochemical indicators of salinity tolerance in plants. Plant Sci. 2004, 166, 3-16. [CrossRef]

45. Khan, M.N.; Siddiqui, M.H.; Mohammad, F.; Naeem, M.; Khan, M.M.A. Calcium chloride and gibberellic acid protect linseed (Linum usitatissimum L.) from $\mathrm{NaCl}$ stress by inducing antioxidative defence system and osmoprotectant accumulation. Acta Physiol. Plant. 2010, 32, 121-132. [CrossRef]

46. Asadi, M.; Heidari, M.A.; Kazemi, M.; Filinejad, A.R. Salicylic acid induced changes in some physiological parameters in chickpea (Cicer arietinum L.) under salt stress. J. Agric. Technol. 2013, 9, 311-316.

47. El Moukhtari, A.; Cabassa-Hourton, C.; Farissi, M.; Savouré, A. How Does Proline Treatment Promote Salt Stress Tolerance During Crop Plant Development? Front. Plant Sci. 2020, 11, 1127. [CrossRef] [PubMed]

48. Trotel, P.; Bouchereau, A.; Niogret, M.F.; Larher, F. The fate of osmo-accumulated proline in leaf discs of Rape (Brassica napus L.) incubated in a medium of low osmolarity. Plant Sci. 1996, 118, 31-45. [CrossRef]

49. Woodward, A.J.; Bennett, I.J. The effect of salt stress and abscisic acid on proline production, chlorophyll content and growth of in vitro propagated shoots of Eucalyptus camaldulensis. Plant Cell Tissue Organ Cult. 2005, 82, 189-200. [CrossRef]

50. Zlatić, N.; Jakovljević, D.; Stanković, M. Temporal, Plant Part, and Interpopulation Variability of Secondary Metabolites and Antioxidant Activity of Inula helenium L. Plants 2019, 8, 179. [CrossRef]

51. Metwally, R.A.; Abdelhameed, R.E. Impact of Ridomil, Bavistin and Agrothoate on arbuscular mycorrhizal fungal colonization, biochemical changes and potassium content of cucumber plants. Ecotoxicology 2019, 28, 487-498. [CrossRef]

52. Rezazadeh, A.; Ghasemnezhad, A.; Barani, M.; Telmadarrehei, T. Effect of Salinity on Phenolic Composition and Antioxidant Activity of Artichoke (Cynara scolymus L.) Leaves. Res. J. Med. Plants 2012, 6, 245-252. [CrossRef]

53. Li, J.; Ou-Lee, T.M.; Raba, R.; Amundson, R.G.; Last, R.L. Arabidopsis flavonoid mutants are hypersensitive to UV-B radiation. Plant Cell 1993, 5, 171-179. [CrossRef]

54. Ismail, H.; Maksimovic, J.D.; Maksimovic, V.; Shabala, L.; Zivanovic, B.D.; Tian, Y.; Jacobsen, S.-E.; Shabala, S. Rutin, a flavonoid with antioxidant activity, improves plant salinity tolerance by regulating $\mathrm{K}^{+}$retention and $\mathrm{Na}^{+}$exclusion from leaf mesophyll in quinoa and broad beans. Funct. Plant Biol. 2016, 43, 75-86. [CrossRef] 
55. Neffati, M.; Sriti, J.; Hamdaoui, G.; Kchouk, M.E.; Marzouk, B. Salinity impact on fruit yield, essential oil composition and antioxidant activities of Coriandrum sativum fruit extracts. Food Chem. 2011, 124, 221-225. [CrossRef]

56. Qureshi, M.I.; Abdin, M.Z.; Qadir, S.; Iqbal, M. Lead induced oxidative stress and metabolic alterations in Cassia angustifolia Vahl. Biol. Plant. 2007, 51, 121-128. [CrossRef]

57. Abdel Latef, A.A.; Mostofa, M.G.; Rahman, M.M.; Abdel-Farid, I.B.; Tran, L.S.P. Extracts from yeast and carrot roots enhance maize performance under seawater-induced salt stress by altering physio-biochemical characteristics of stressed plants. J. Plant Growth Regul. 2019, 38, 966-979. [CrossRef]

58. Sicher, C.; Barnaby, J.Y. Impact of carbon dioxide enrichment on the responses of maize leaf transcripts and metabolites to water stress. Physiol. Plant. 2012, 144, 238-253. [CrossRef]

59. Warren, C.; Aranda, I.; Cano, F.J. Metabolomics demonstrates divergent responses of two Eucalyptus species to water stress. Metabolomics 2012, 8, 186-200. [CrossRef]

60. Becerra-Moreno, A.; Redondo-Gil, M.; Benavides, J.; Nair, V.; Cisneros-Zevallos, L.; Jacobo-Velázquez, D.A. Combined effect of water loss and wounding stress on gene activation of metabolic pathways associated with phenolic biosynthesis in carrot. Front. Plant Sci. 2015, 6, 837. [CrossRef]

61. Matallo, M.B.; Almeida, S.D.B.; Franco, D.A.S.; Cerdeira, A.L.; Gazzeiro, D.L.P. Glyphosate as a tool to produce shikimic acid in plants. Planta Daninha 2014, 32, 601-608. [CrossRef]

62. Herrmann, K.M.; Weaver, L.M. The shikmate pathway. Annu. Rev. Plant Physiol. Plant Mol. Biol. 1999, 50, 473-503. [CrossRef] [PubMed]

63. Jacobo-Velázquez, D.A.; Cisneros-Zevallos, L. Correlations of antioxidant activity against phenolic content revisited: A new approach in data analysis for food and medicinal plants. J. Food Sci. 2009, 74, 107-113. [CrossRef]

64. Chen, Z.; Silva, H.; Klessig, D.F. Active oxygen species in the induction of plant systemic acquired resistance by salicylic acid. Science 1993, 262, 1883-1886. [CrossRef]

65. Jaiswal, A.; Pandurangam, V.; Sharma, S.K. Effect of salicylic acid in soybean (Glycine max L. Meril) under salinity stress. Int. J. Life Sci. Res. 2014, 9, 671-676.

66. Singh, S.; Singh, V.P.; Prasad, S.M.; Sharma, S.; Ramawat, N.; Dubey, N.K.; Tripathi, D.K.; Chauhan, D.K. Interactive Effect of Silicon (Si) and Salicylic Acid (SA) in Maize Seedlings and Their Mechanisms of Cadmium (Cd) Toxicity Alleviation. J. Plant Growth Regul. 2019, 38. [CrossRef]

67. Dubois, M.; Gilles, K.A.; Hamilton, J.K.; Rebers, P.A.; Smith, F. Calorimetric method for determination of sugars and related substances. Anal. Chem. 1956, 28, 350-356. [CrossRef]

68. Lee, Y.P.; Takanashi, T. An improved colorimetric determination of amino acids with the use of ninhydrin. Anal. Biochem. 1966, 14, 71-77. [CrossRef]

69. Bates, I.S.; Waldern, R.P.; Teare, I.D. Rapid determination of free proline for water stress studies. Plant Soil 1973, 39, 205-207. [CrossRef]

70. Jindal, K.K.; Singh, R.N. Phenolic content in male and female Carica papaya: A possible physiological marker sex identification of vegetative seedlings. Physiol. Plant. 1975, 33, 104-107. [CrossRef]

71. Zou, Y.; Lu, Y.; Wei, D. Antioxidant activity of flavonoid-rich extract of Hypericum perforatum L in vitro. J. Agric. Food Chem. 2004, 52, 5032-5039. [CrossRef]

72. Heath, R.L.; Packer, L. Photoperoxidation in isolated chloroplast. I. Kinetics and stoichiometry of fatty acid peroxidation. Arch. Biochem. Biophys. 1968, 125, 189-198. [CrossRef]

73. Zelya, I.A.; Anderson, J.A.H.; Owen, M.D.K.; Landes, R.D. Evaluation of spectrophotometric and HPLC methods for shikimic acid determination in plants: Models in glyphosate resistant and susceptible crops. J. Agric. Food Chem. 2011, 59, $2202-2212$. [CrossRef] [PubMed]

74. Aebi, H. Catalase. In Methods of Enzymatic Analysis; Bergmeyer, H., Ed.; Elsevier: Amsterdam, The Netherlands, 1983 ; pp. 273-286. [CrossRef]

75. Maehly, A.C. Assay of catalases and peroxidases. In Methods of Biochemical Analysis; Glick, D., Ed.; Wiley: Hoboken, NJ, USA, 1955; Volume 2, pp. 764-775. [CrossRef]

76. Kar, M.; Mishra, D. Catalase, peroxidase and polyphenol oxidase activities during rice leaf senescence. Plant Physiol. 1976, 57, 315-319. [CrossRef] [PubMed]

77. Nakano, Y.; Asada, K. Hydrogen peroxide is scavenged by ascorbate-specific peroxidase in spinach chloroplasts. Plant Cell Physiol. 1981, 22, 867-880. [CrossRef] 